\title{
Physical Recreation of Students of Selected Warsaw Non-Public Higher Education Institutions - Preferences and Motivations
}

\author{
Andrzej Dąbrowski, Joanna Radiuk-Strzeżek
}

Josef Pilsudski University of Physical Education in Warsaw, Poland

\section{KEYWORDS}

ABSTRACT

The creation of conditions within the teaching and educational system of higher education institutions that shape up rational, pro-health free-time behaviours is one of the key goals of the studies discussed in this paper. The starting point for every planned educational process is to investigate the present state of affairs, i.e. to perform a diagnosis. This paper presents the diagnosis results which indicate, based on the empirical research findings, the forms of leisure activities most often pursued and the motivations behind them. The method we used in our research was a diagnosis survey which covered 1,119 students.

The dominant leisure-time activities preferred by the students we surveyed were watching TV and meeting friends. The third most popular student leisure activity was in the case of men spending time in front of a computer and in the case of the women walking. Nearly half of the female students and a little more than half of the male students practise their recreational activities outside the official school physical education classes. The men practise a little more often than the women. Football, cycling and swimming are the most popular sports among the men. The women prefer bicycle riding, gymnastic exercises, aerobics and volleyball. Both the male and female students gave as their first two most important motives for recreational physical activities their health and fitness aspects. The third motive varies, depending on sex. The female students appreciate rest and relaxation which they achieve through recreational physical activities. The men highlight the value of being in touch with nature. Although the students from the surveyed group say they do not engage in physical activity in their free time in any planned way, nearly $50 \%$ of them do so on a regular basis.

students, physical recreation, motivation, participation preferences

\section{Introduction}

The lifestyle we choose to lead, often intuitively, has a significant impact on our physical and mental state and health. Of many elements of lifestyle physical movement is the second most 
important factor, after eating, determining a person's behaviour. Physical activity is the element of lifestyle which conditions in the most beneficial way the morphology and functionality of a human body and shapes our mental qualities. It significantly enhances the efficiency of a human immune system (Kasperczyk 1998).

Physical activity determines the level of fitness and physical work capacity, and these two elements are closely related to health. Insufficient amount of physical activity (as well as incorrect physical activity - excessive, too intensive, or incorrectly selected forms of physical activity) may lead to many disorders and increased risk of disease. One may therefore say that physical activity is one of the determinants of our health.

A person's physical activity is also an area of social interest. Because of the link between physical activity and health, physical activity is of value not only to individuals but also to society as a whole; "persons who are physically inactive are more exposed to the risk of developing a disease, disability or premature death" (Drabik 1997).

"On the one hand, regular participation in physical activity is recommended for adults or even regarded as a must (as a means of maintaining good health). But on the other hand, it is quite frequently subject to numerous limitations resulting mainly from the specifics of the adult life: having to cope with an increasing number of professional, family and social duties" (Wolańska, Salita, Piotrowska 1998, p. 12). However, doing physical exercise at this stage of life plays a number of important health, social, preventive, socialising and other functions. But whether one opts for an active lifestyle depends on a number of factors. The negative factors, deterring or preventing adults from engaging in physical activity, include in particular: diseases, financial barriers, subjective sense of not having free time, new professional and/or family duties. Among the positive factors which increase adults' willingness to participate in recreational physical activities on a regular basis are: "having stability in life, positive sports experiences gained in childhood, adoption of new lifestyle models and patterns by young people, or the phenomenon called late blooming connected with grown up children leaving home" (Wolańska, Salita, Piotrowska 1998, p. 14).

Kunicki (1993) believes there are four main groups of barriers to physical activity of adults: ideological, cognitive, psychological, and cultural. Drabik (1997a) has identified three groups of factors influencing participation in physical activity: personal, community, and features of physical activity. J. Drabik mentions also the most frequent reasons why adults decide not to participate in programmes of physical activity. The reasons given most often are: lack of time, lack of motivation and progress, the fact that participants have little influence on the exercise programme, excessive costs, the place of exercise is too far away, excessive body weight, smoking, high risk of injury, lack of awareness of how important physical activity is to maintaining good health. When asked why they take up physical activity, adults most often give the following reasons: "enhanced functional fitness of the body, shedding excessive weight, doctor's recommendations, improved appearance, better state of mind, improved ability to cope with stress, sounder sleep" (Drabik 1997a, p. 22).

Today free time plays an increasingly important role in the life of contemporary humans. It is no longer seen as just the time of rest or recovery after work, but also as the time during which one can pursue one's interests or satisfy various intellectual, social, cultural and sporting needs.

However, the way today's students use their free time is not without problems. One of them is the well-known situation of the great majority of evening/weekend students, particularly those studying at private higher education institutions. They usually have classes on weekends. Most such students work, and some have families and children. Clearly this is not a situation that can encourage anyone to engage in any creative activities in his/her free time. Many studies have shown that one of 
the most common barriers to physical recreation is the lack of free time (Salita-Lisowska 2006, pp. 139-153).

The situation of full-time students is slightly different. The amount of discretionary time at their disposal allows them to engage in various activities, including recreation and sports. Among the many forms of physical recreation pursued by adult Poles are for example cycling, gardening and swimming (Lisowska 2005).

Given the important role leisure plays in the process of shaping personality and character there appear to be legitimate reasons why attention should be drawn to the motivations behind decisions to choose a certain type of behaviour during free time. Theoretical background of the motivation has been developed by Winiarski (1991) among others. He developed a questionnaire to find out what motivates people to participate in recreational physical activities. The research conducted to date shows that young adults are more often driven in their decisions by emotions rather than rational reasons. This seems to suggest that the teaching systems of higher education institutions should be modified to create conditions that would encourage and promote rational and healthy free-time behaviours. The starting point for every planned educational process is to investigate the present state of affairs, i.e. to perform a diagnosis. We present our diagnosis in the further part of this paper. Based on the empirical research findings we present the forms of activities most often pursued in free time and the motivation behind them.

The purpose of the research, the problems being investigated, the research method and the hypothesis proposed, and the description of the group being researched

The purpose of our research was to establish the patterns and intensity of physical recreation of students from non-public higher education institutions in Warsaw, and to find out the conditions in which they engage in such activities. We were particularly interested to find out what forms of physical recreation are most popular among those students and what factors determine their participation in them.

Therefore, the question we were seeking to answer through our research was what forms of physical recreation were preferred by those students and what motives drove them to engage in physical recreation.

The method we used in our research was a diagnosis survey. Our technique was a questionnaire, observation, and analysis of documents. Our tools were a survey questionnaire and an observation sheet.

The research was carried out between December 2006 and January 2008 and covered 1,119 students from three higher education institutions based in Warsaw.

The analysis of the literature on the subject and the experience gained while working with students of the above schools, led us to postulate the following scientific hypotheses:

- Students of non-public schools show the greatest interest in team sports and swimming.

However, these interests vary between women and men. Female students tend to choose activities involving recreational gymnastic and fitness exercises.

- Among the motives most frequently cited by the students covered by the research were the desire to be with their peers (a social motive) and the pleasure derived from participation in a recreational physical activity (ludic motivation). 
Our research covered full-time and part-time/evening/weekend students of level I and level II studies. The group we researched included 652 women and 467 men.

By 30 September 2008, we had collected 1,119 filled-in "My physical activity" questionnaires. We also carried out an open participatory observation of that group. Our research findings also included the results of our analysis of documents.

The average age of the students was 22. Full-time students were the largest subgroup. Within that group were 212 men (53\%) and $272(47 \%)$ women. The second largest subgroup were parttime/evening/weekend students: 179 men (45\%) and 302 women (52\%). Only $2 \%$ of evening students participated in the research.

The emergence of non-public higher education institutions coincided with the reform of Poland's higher education system. New regulations were enacted which created two distinct levels of higher education: B.A. studies (today referred to as level I studies) and M.A. studies (today referred to as level II studies).

The largest subgroup in the group of students we researched were B.A. students, i.e. level I students - representing $91 \%$ of all the men (309) and $86 \%$ of all the women (479) we surveyed. The second largest subgroup were level II students (continuous M.A. students - representing $7 \%$ of all the women (41) and 5\% of all the men (18)) and post B.A. Students - representing $7 \%$ of all the women (39) and $4 \%$ of all the men (13) we surveyed.

Although the education institutions covered by the survey are based in Warsaw, their students graduated from secondary schools located in many different cities and towns. $48 \%$ of the women (314) and $55 \%$ of the men (255) received their secondary education diplomas from schools located in large cities (i.e. having more than 100,000 residents), and $48 \%$ of the women (310) and $39 \%$ of the men (182) from schools located in smaller cities and towns (10,000-100,000 residents). The smallest group is those who attended a secondary school located in a village - $4 \%$ of the women (27) and $6 \%$ of the men (28).

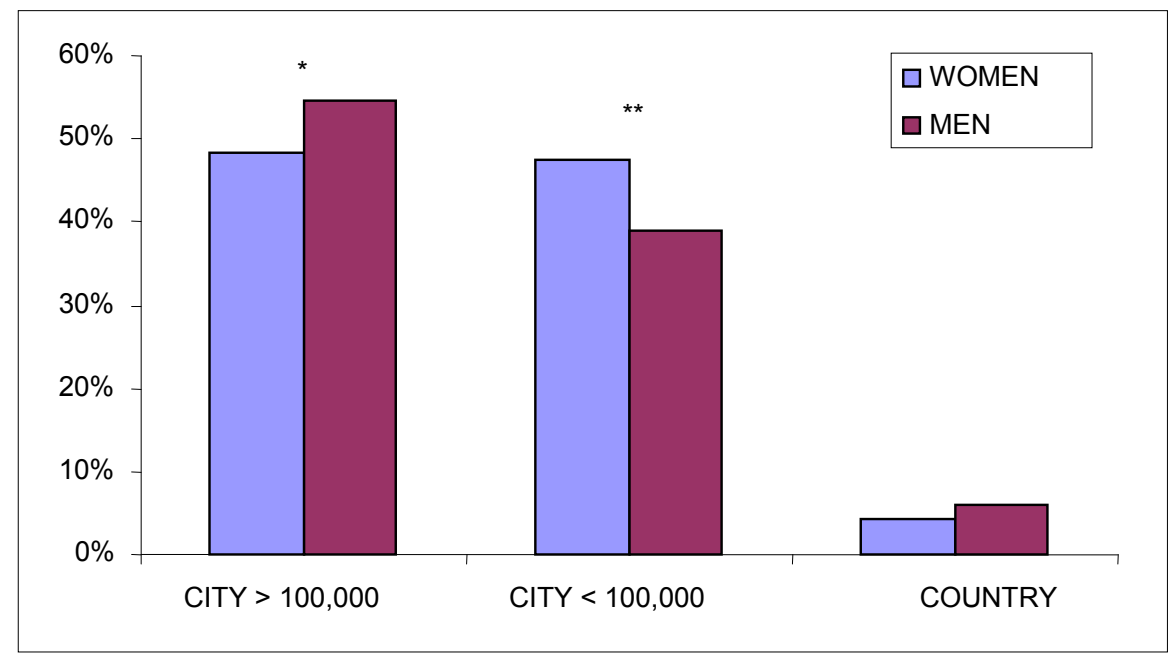

Figure. 1. Profile of the surveyed persons - by the location of their secondary school Source: Personal research

In line with the trend seen in today's society to marry later in life than before (Parnicka 2003), married persons represented only $8 \%$ of all the women (52) and $4 \%$ of all the men (17) we researched. The rest were singles, i.e. $96 \%$ of the men (452) and $92 \%$ of the women (600). 


\section{Research results}

Educating people about leisure-time behaviours is one of the most important goals of education. This goal is being pursued by all the communities involved in intentional education of people whereas in fact it should also be pursued by all the communities providing natural educational (primarily families).

Leisure-time education and its dynamic development in recent years signal an increasing need to educate about this area of life. This is due among others to technological progress in our everyday life, more generally, and to an increase in the amount of discretionary time. The majority of the students we researched, including full-time day students, combine studying with working; therefore they have very limited amounts of leisure time to spend. Accordingly, what they do in their free time becomes an especially important question.

The research findings we gathered demonstrate that $80 \%$ (572) of the women covered say watching TV is their number one leisure activity. They watch TV on average 4 times a week, spending an average of one hour and a half per day (91.59 minutes/per day).

The men say watching TV is their second most common leisure activity ( $80 \%$ or 374$)$, yet they spend more time watching TV than the women - about 5 times a week. On an average day the students spend close to 2 hours (112.73 minutes/per day) in front of the box.

Social gatherings are the second most commonly practised form of leisure activity mentioned by the female students (78\%). This is the number one form of leisure activity for the men $(82 \%)$. The women meet with friends on average 3 times per week and spend close to 3 hours $(175.87$ minutes) each day meeting friends. The men meet 5 times a week and spend more than 3 hours (196.41 minutes) on such meetings.

The above research results, demonstrating that watching TV and meeting friends are the most popular forms of leisure time activities among the students, confirm that these forms of leisure activities enjoy popularity among adult Poles (Mogiła-Lisowska 2010).

What is striking in these results is that they show that young people spend almost no time practising physical activities which are so characteristic for this age group. They show no need to get rid of pent-up energy which is something very natural at this age. What then stifles so effectively this natural urge to engage in physical activity in the persons being researched? Our results contain enough information for us to be able to answer this question. The primary goal the students want to achieve in their free time is to rest and relieve mental stress caused by studying and working (a significant part of the students - $68 \%$ - combine study and work).

The third most popular form of leisure activity among the women is walking; 75\% (489) of them declare they go on a walk about 4 times a week and spend each time a little more than one hour (77.04) walking. The third most popular form of physical activity among the male students is spending time in front of a computer; 74\% (346) declare they spend nearly 3 hours (164.83 minutes) 6 times a week in front of a computer. Other detailed information about leisure-time activities is shown in Figure 2. 


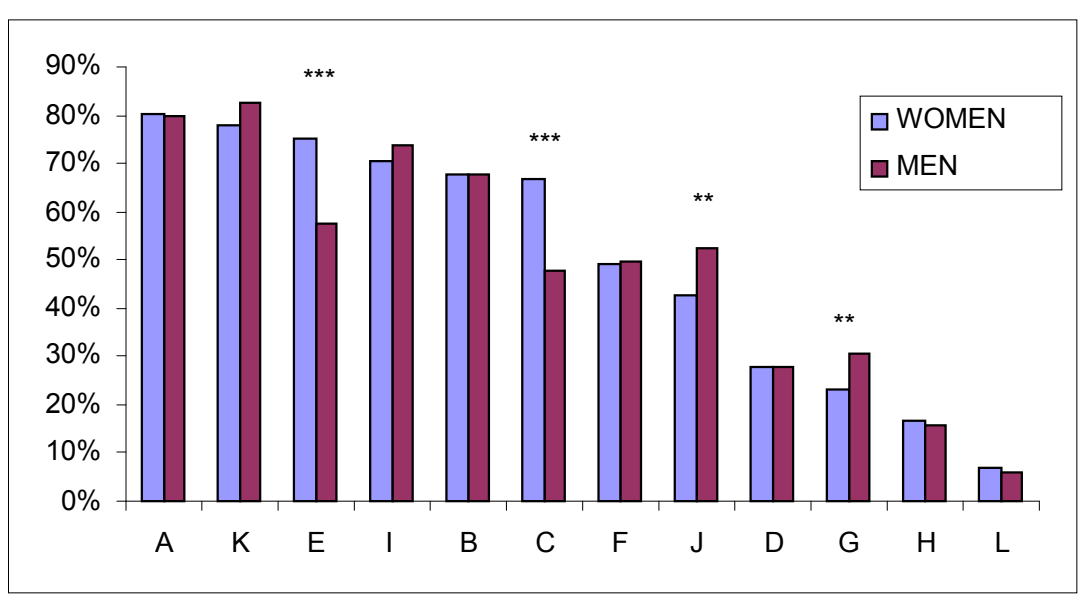

Figure 2. Percentage of recreational activities per week Source: Personal research

A - watching TV, B - passive leisure (sleeping, lying down, a nap), C - reading, D- cinema/theatre, Ewalking, $\mathrm{F}$ - bicycling (weather permitting), $\mathrm{G}$ - swimming, $\mathrm{H}$ - going to a gym, I- computer, $\mathrm{J}$ hobby, K- meetings with friends, $\mathrm{L}$ - other (what?)

Surely, these patterns of leisure-time behaviours seen in the students covered by our research run counter to the premises on which health education is based and to the recommendations regarding leisure time which are formulated by the most distinguished scientists and theoreticians of leisure time education, health education, and the theory of physical recreation (Demel, Kunicki, Drabik, Wolańska and others). However, they reflect primary needs of the persons concerned.

Moreover, one can also point out other categories of determinants of these types of behaviours:

- widespread availability of passive forms of leisure activities,

- customs relating to spending free time present within one's own community,

- the role of television and computers as the source of knowledge and entertainment,

- fatigue and lack of strength for other active forms of leisure activities,

- absence of any offer from the peers to engage in physical activity, and if such offers exist, they have little appeal.

In the group of students who spend their discretionary time actively, clear differences are seen in the forms of activity chosen by men and women.

The full picture of the preferred forms of physical activity among the students covered by the research is shown in Figure 3.

The choice of forms of physical activity depends on a number of factors. Such choices are often prompted by the needs arising from past experience. Also, external circumstances, such as for example availability, also play a role in that process.

The profile of the students' interest in specific forms of recreation confirms the earlier research results. The most popular form of physical recreation is football. Nearly half of the researched students declare that they participate in such activity at least once a week. 49\% (229) said they played football sporadically.

It is no surprise that the research students consider team sports, and especially football, to be the most attractive forms of physical recreation. Football, just like other team sports, is a highly attractive 
means of releasing internal tensions and burning off pent-up energy through physical activity. As Kiełbasiewicz-Drozdowska and Siwiński have so aptly put it: "Games satisfy the need to achieve success; they help release pent-up aggression and satisfy the urge to compete. They provide an opportunity to be active. They also enable people who play games to express their ego by giving satisfaction to people who cannot get satisfaction in other areas of life. Also, they compensate for frustration and boost self-esteem" (Kiełbasiewicz-Drozdowska, Siwiński, 2001, p. 290).

It is also worth adding that aerobic exercises allow people to properly develop physically and help prevent many diseases (obesity, hypertension, diabetes) (Żukowska-Kowalska and others 2005, p.5).

The second most frequent form of physical recreational activity practised by the men is cycling; $43 \%$ (201) of them said they had cycled at least once every week during the past year, and $35 \%(164)$ had cycled sporadically.

Cycling is the most popular form of physical recreation among the women. More than half of them ride a bicycle (55\% or 359) no less frequently than once a week, and $40 \%$ (261) ride a bicycle sporadically. Swimming came third. 38\% (248) of the men swim at least once a week and $43 \%$ (286) of them swim sporadically.

Gymnastic exercises, aerobics and other forms of fitness exercises are the second and third most popular forms of sports activities among the female students. $41 \%$ of them do gymnastic exercises once a week, and $31 \%$ sporadically. $37 \%$ of them go to aerobics classes and do similar fitness exercises once a week, and $31 \%$ of the female students surveyed participate in such activities sporadically.

The value of fitness is highlighted for example by Olex-Zarychta (2005), who points out the sense of contentment and satisfaction and relaxation experienced during fitness training. Opinions about aesthetic values of fitness can also be found, for example, in the papers by Mattelli (2008), Biernacki and others (2004).

All these opinions seem to find confirmation in the responses given by the female students, who prefer fitness to other forms of physical activity.

Cycling and volleyball are equally popular among the male and female students. The other most frequently practised forms of physical activity are however ranked differently by men and women.

Both the most frequently practised forms of physical activity are capable of significantly enhancing overall fitness. Bicycle riding is one of the most popular aerobic activities and volleyball is an excellent sport ensuring all-round athletic development.

The profile of the physical activity preferences presented above is made complete by the empirical data which show what forms of physical recreation are practised sporadically by the students surveyed. These data are shown in Figure 3.

These data confirm the high popularity of team sports among the male students and of volleyball and swimming among the female students.

As transpires from these data, the selection of individual forms of physical activity follows certain standard patterns. This is probably the result of physical education programs implemented at all levels of education. These programs shape up the image of physical culture among students and teach them certain patterns of behaviour which in turn generate needs and affect free-time behaviours. The students surveyed by us do not prefer innovative forms of physical activity which have emerged in a large number in recent decades. These new forms have led to the development of a new market 
offering a wide range of options which have rekindled interest in physical recreation the world over. This is hardly the case with the young adults we surveyed. Apart from fitness, which attracts some of the female students we surveyed, traditional forms of physical activity dominate: walking and cycling and (traditional) team sports and swimming.

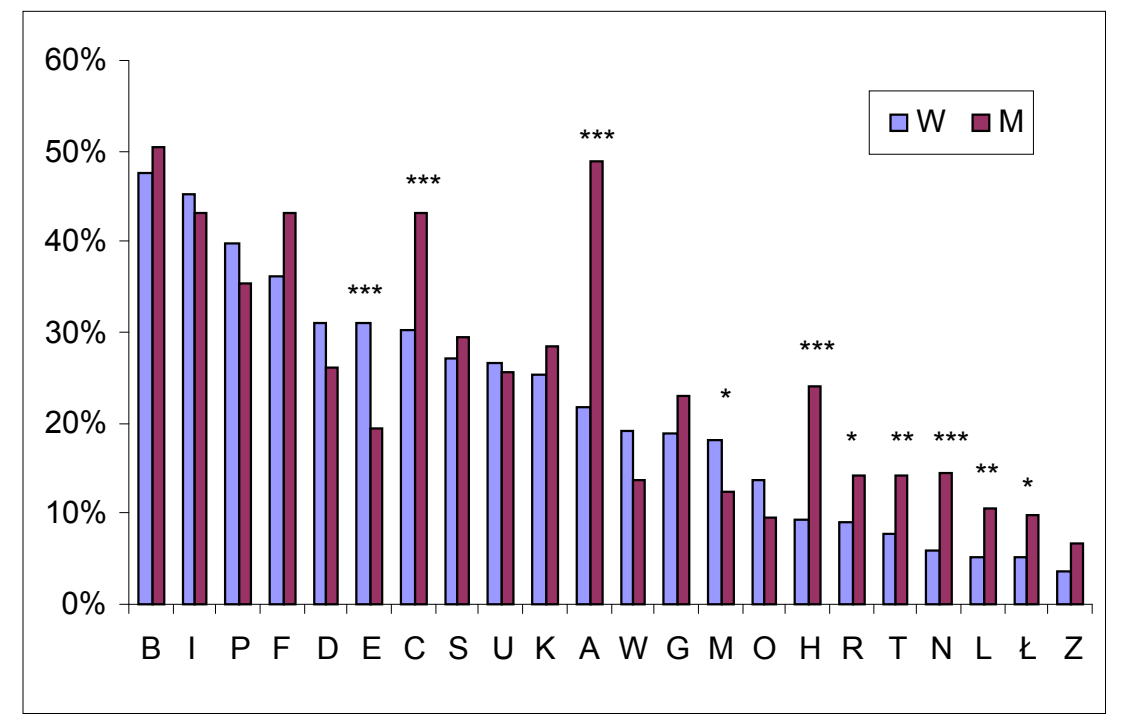

Figure 3. Sporadic participation in a physical activity

Source: Personal research

A - football, B - volleyball, C - basketball, D - gymnastics/physical exercises, E- aerobics and similar, F - table tennis, $\mathrm{G}$ - tennis, $\mathrm{H}$ - body building, I- swimming, $\mathrm{K}$ - skiing, snowboarding, L- gliding, $\mathrm{L}$ - parachuting, $\mathrm{M}$ jogging, $\mathrm{N}$ - martial arts, $\mathrm{O}$ - horse riding, $\mathrm{P}$ - cycling, $\mathrm{R}$ - climbing, $\mathrm{S}$ - sailing/yachting, $\mathrm{T}$ - windsurfing, $\mathrm{U}$ mountain trekking, $\mathrm{W}$ - inline skating, $\mathrm{Z}$ - other

One of the key questions that need answering in the analysis of leisure-time behaviours of the students surveyed is why they engage in sports activities in the first place?

Past research into this question shows that the main motivation driving the adult Polish population to do sports is to maintain health and keep fit (Lisowska 2005).

Many of the persons we researched prefer forms of activity which contain sports elements (competition, possibility of testing one's capabilities and fitness). But there are also persons whose motivation is personal development and self-improvement. "Recreational sport, just like tourism, involves elements of personal development because both sport and activity-based tourism are about self-betterment" (Jędrzejczyk 2002, p. 93).

There are many reasons why it is good to do exercise and be active. The respondents are well aware of health aspects of physical activity. Both the women (58\% or 378$)$ and men (51\% or 333) consider this to be the most important benefit of physical activity. $51 \%$ of the men admit physical exercises are a good way to rest and relax. Both the women $(51 \%)$ and men $(49 \%)$ say the need to stay fit is the reason why they engage in recreational physical activity.

The motivations of the students we surveyed seem to be consistent with the opinion formulated by Koszczyc, who writes that "The level of physical fitness significantly determines the biological value of a man, his feeling and quality of life. And these are the main reasons why physical fitness is considered by many to be a positive measure of health" (Koszczyc and others 2007, p. 22). 
The third most frequent motivation given by the female students is the willingness to rest and relax during recreational and physical activities (49\% or 309). In the case of the men, it is the value of the contact with nature and being outdoors $(30 \%$ or 140$)$.

The women we surveyed also appreciate the weight-controlling benefits of physical activity. $36 \%$ or 235 are of the opinion that physical activity helps them control their body weight. $29 \%$ of the men are aware of the link between recreational and physical activities and emotions, the possibility of living an adventure and having fun. Detailed information about motivations for physical activity is given in Figure 4.

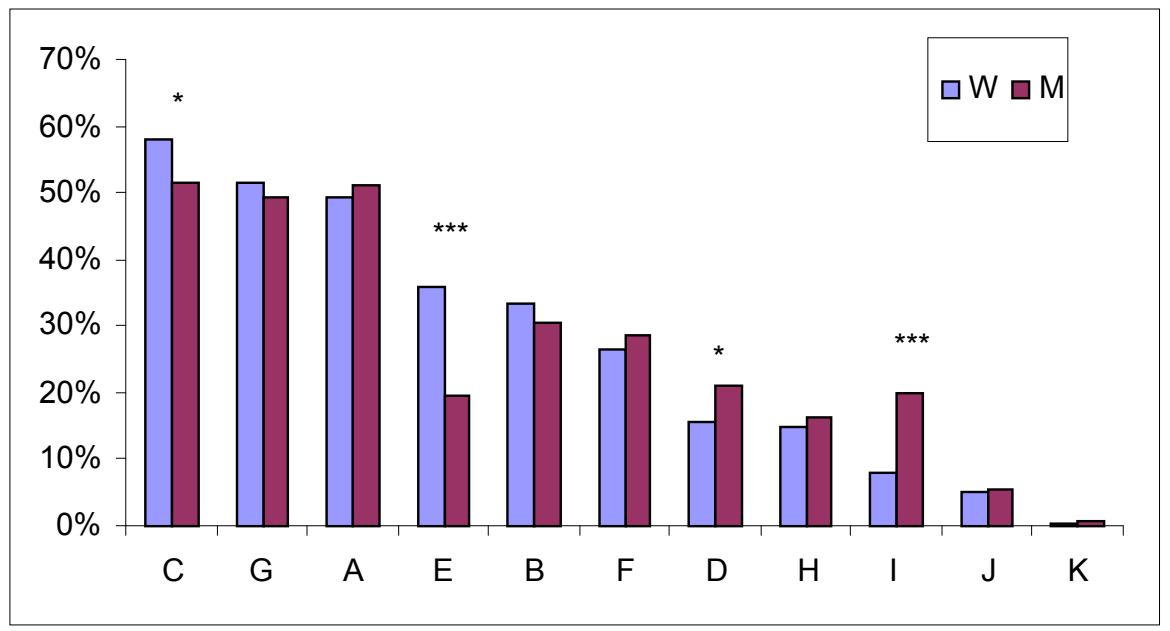

Figure 4. Physical activity motivation

Source: Personal research

A - rest, relaxation, $\mathrm{B}$ - being outdoor, $\mathrm{C}$ - maintaining health, D - being in a group, E- controlling body weight, $\mathrm{F}$ - entertainment, experiencing an adventure, emotions, $\mathrm{G}$ - being fit, $\mathrm{H}$ - self-realization, I- enjoying competition, $\mathrm{J}-$ to be more effective at work, $\mathrm{K}$ - other (what?)

\section{Conclusions}

1. The dominant leisure-time activities preferred by the students we surveyed were watching TV and meeting friends. The third most popular student leisure activity was in the case of the men spending time in front of a computer and in the case of the women walking.

2. Nearly half of the female students and a little more than half of the male students practise their recreational activities outside the official school physical education classes. The men practise a little more often than the women.

3. Football, cycling and swimming are the most popular sports among the men. The women prefer bicycle riding, gymnastic exercises, aerobic and volleyball.

4. Both the male and female students gave as their first two most important motives for recreational physical activities their health and fitness aspects. The third motive varies, depending on sex. The female students appreciate rest and relaxation, which they achieve through recreational physical activities. The men highlight the value of being in touch with nature.

Although the students from the surveyed group say they do not engage in physical activity in their free time in any planned way, nearly $50 \%$ of them still do so on a regular basis. 
Given the most frequently cited motives for recreational physical activity and the forms of recreational physical activity preferred by the group we surveyed, one has to conclude that efforts to encourage them to be more active should be based on the promotion of healthy and fitness-enhancing forms of physical recreation.

The inclusion in recreation programs for students of the forms of activity which enjoy the greatest popularity among them today and increasing their awareness of health and fitness-enhancing aspects of those most popular and other innovative forms, is expected to encourage those who already engage in such activities to do so on a more regular basis and to foster in those who don't the need to be more active.

\section{REFERENCES}

Biernacki, J., Niedziółka, A., Marszałek, S. (2004). Fitness, jogging. Poradnik dla instruktorów rekreacji ruchowej /Fitness, jogging. Fitness instructor handbook/.

Biernat, E., Dąbrowska, A. (2006). Rola szkoły we wdrażaniu do rekreacji ruchowej uczniów /The role of schools in getting children into the habit of being physically active/. In A. Dąbrowski (Ed.) Zarys teorii rekreacji ruchowej /An outline of the theory of physical recreation/. Warsaw: Almamer, AWF Warszawa, p. 59.

Drabik, J. (1997). Promocja aktywności fizycznej/Promotion of physical activity/. AWF Gdańsk, p. 12.

Drabik, J. (1997a). Promocja aktywności fizycznej (wprowadzenie do problematyki)/Promotion of physical activity (introduction into the issues)/ cz.III. AWF Gdańsk, p. 22.

Jędrzejczyk, I. (2002). Rozwój funkcji turystycznej i rekreacyjnej polskich obszarów górskich /Development of the tourist and recreational functions of mountain regions/. Katowice: AWF, pp.13; 88; 93.

Kasperczyk, T. (1998). Aktywność ruchowa jako składowa profilaktyki zdrowia ze szczególnym uwzględnieniem układu odpornościowego /Physical activity as an element of preventive health care, particularly as a measure of boosting the immune system/. In E. Rutkowska (Ed.) Aktywność fizyczna w pielegnowaniu zdrowia $i$ terapii chorób /The role of physical activity in health care and treatment of diseases/. Lublin: Akademia Medyczna.

Kiełbasiewicz-Drozdowska, I., Siwiński, W. (2001). Teoria i metodyka rekreacji (zagadnienia podstawowe). /Theory and methodology of recreation (basic issues)/. Poznań: Wydawnictwo AWF Poznań, p. 290.

Koszczyc, T., Wołyń, J., Guła-Kubaszewska, M., Paliga, Z. (2007). Aktywność ruchowa dzieci i młodzieży. /Physical activity of children and young people./ Wrocław: Wydawnictwo AWF, p. 22.

Kunicki, B. J. (1993). Aktywność ruchowa w promocji zdrowia - niedomagania i bariery. /Physical activity in the promotion of health - shortcomings and barriers/. In B. J. Kunicki, K.Szyszka (Eds.) Kultura fizyczna w promocji $i$ doskonalenia zdrowia. /Physical culture in the promotion and improvement of health/. Gorzów: PTNKF, pp. 45-53.

Lisowska, J. (2005). Uczestnictwo Polaków w sporcie dla wszystkich - popularność wybranych form. In Z. Dziubiński (red.) Sport jako kulturowa rzeczywistość /Participation of Poles in sports for everyone - the popularity of selected forms/. In Z. Dziubiński (Ed.) Sport as a cultural reality. Warszawa: SALOS RP.

Matella, K. (2008). Fitness, zdrowie i uroda /Fitness, health and beauty/, wyd. Literat.

Mogiła-Lisowska, J. (2010). Rekreacyjna aktywność ruchowa dorostych Polaków - uwarunkowania i styl uczestnictwa. IPhysical recreational activity of adult Poles - determinants and style of participation/. Monografie AWF, Warszawa.

Olex-Zarychta, D. (2005). Fitness teoretyczne i metodyczne podstawy prowadzenia zajęć (podręcznik dla studentów wychowania fizycznego i instruktorów fitness)/Fitness - theoretical and methodological background for conducting fitness classes (handbook for physical education students and fitness instructors)/ Wydanie II. Publikacja powstała przy udziale Fundacji Akademii Wychowania Fizycznego w Katowicach. Katowice, p. 70.

Parnicka, U. (2003). Zachowania zdrowotne kobiet czynnych zawodowo. /Health related behaviours of professionally active women/. Kultura Fizyczna, no. 3-4. 
Salita-Lisowska, J. (2006). Poles` Participation in Sport for All-Motivations and Barriers. In J. Kosiewicz (Ed.) Movement recreation for all. Legionowo, Warszawa: BK Wydawnictwo i Księgarnia. ISBN 83-89829-21-5, pp. 139-153.

Winiarski, R. (1991). Motywacje aktywności rekreacyjnej człowieka. /People's motivations for physical recreational activities/. Kraków: AWF, pp. 12-17.

Wolańska, T., Salita, J., Piotrowska, H. (1998). Sport dla wszystkich w cyklu życia. /Sport for everyone in a lifecycle/. Wychowanie Fizyczna i Sport, nr 2, pp. 11-14.

Żukowska-Kowalska, K., Jóźków, P., Mędraś (2005). Metodyczne aspekty turystyki i rekreacji. /Methodological aspects of tourism and recreation./ Wrocław: Wydawnictwo AWF Wrocław, p. 5. 